\title{
O REINO VISIGODO: CATOLICISMO E PERMANÊNCIAS PAGÃS
}

\author{
Ruy de O. Andrade Filho* \\ ruy.andrade@uol.com.br
}

Resumo: O que se costumou chamar de "paganismo" é, sem dúvida, uma das formas mais significativas daquilo que se costumou designar por "religiosidade popular". Tal expressão, que parece útil quando se pretende uma generalização, mostra toda sua fragilidade quando se tenta uma observação mais precisa e objetiva de uma determinada religiosidade. A "conversão" oficial do reino visigodo ao catolicismo, com Recardo (586-601) no concílio de Toledo de 589 teria, efetivamente, correspondido à "conversão" da população desse reino? Em primeiro lugar, é necessário que consideremos, para além das intenções exaltadoras das fontes desse momento, que as "conversões" em massa não implicam uma mudança radical nas convicções e práticas religiosas de todo um povo. Em segundo, que "conversão" e "cristianização" não são sinônimos. A "religiosidade", onde se insere a "conversão", implica uma atitude religiosa fundamental, que pode ser simplesmente interior e pessoal. Por seu turno, a "religião", que engloba a "cristianização", corresponderia a um aspecto público, institucionalizado, que elabora um conjunto de técnicas dirigidas que visa, como no caso da "religiosidade", a garantia do sobrenatural. Assim, alçada ao posto de "religião oficial", o cristianismo católico passaria a conviver com uma série de ritos, cultos, devoções, oriundos da "religiosidade" anterior e que, sob sua ótica eclesiástica, seriam condenáveis, consideradas marginais e que conduziriam ao erro. Contudo, às vésperas da invasão muçulmana em 711, não somente entre os laicos mas inclusive nos segmentos eclesiásticos, as manifestações do chamado "paganismo" ainda eram alvo de condenações coercitivas nos concílios católicos do reino de Toledo.

Palavras-Chave: Cristianização, conversão, paganismo.

* Doutor em História, Professor de História Medieval na UNESP-Assis.

O presente artigo é, em parte, uma paráfrase do primeiro capítulo de nosso livro Imagem e Reflexo. Religiosidade e Monarquia no Reino Visigodo de Toledo (séculos VI-VIII). São Paulo: Edusp, 2012, pp.35-69, acrescentando algumas novas considerações, ampliando informações e aprofundando algumas das idéias ali tratadas. 
Na segunda metade do século VI, João de Bíclaro (aprox. 540-621), bispo de Gerona, registraria num dos títulos de sua Crônica: "O quinto ano de Maurício, príncipe dos romanos, que é o primeiro do rei Recaredo, felizmente". Em seguida, ele nos esclarece: "Recaredo, no primeiro ano de seu reinado, no décimo mês, torna-se católico, com a ajuda de Deus; e tendo-se dirigido aos sacerdotes da seita ariana, através de uma prudente entrevista, mais pela razão que pela força, fez com que se convertessem à fé católica, reintegrando na unidade e na paz da Igreja cristã todo o povo dos godos e dos suevos. A seita ariana, pela graça divina, vem para o dogma cristão". (BICL. Chron. aprox.587,5)

Com essa atitude, Recaredo (586-601) começava a por um fim na grande crise que se instalara na Hispânia entre os anos de 580-590, que ainda hoje desperta apaixonadas polêmicas. Ele encerrava a obra iniciada por seu pai, Leovigildo (571-586) consolidando a unidade política de seu reino por intermédio da unidade religiosa. Os motivos apontados para sua conversão se extendem desde as convicções mais íntimas, passando pelas razões políticas, e chegando até o frágil convencimento dogmático do clero ariano (GONZÁLEZ, 1979, p. 406ss). Mas a crise que precedeu sua conversão é ainda bastante controversa. Ela resultava por um lado, do complexo encadeamento de fatos e intenções e, por outro de um conjunto de atitudes políticas e religiosas. Ela seria desencadeada pela conversão ao catolicismo de Hermenegildo, irmão de Recaredo, no auge da política unificadora arianista de seu pai, agravada pela presença dos enclaves bizantinos na Hispânia Meridional. Muito posterior a esses fatos, uma iluminura hagiográfica, datada de 1586, sob o reinado e instâncias de Felipe II, em plena Reforma Católica faz aparecer a seguinte tríade: Leovigildo o perseguidor, Hermenegildo o mártir, Recaredo o herói da verdadeira fé. De outro lado, a redução a um jogo de forças puramente políticas instiga o esboço de uma outra tríade: Leovigildo unificador e criador da realeza de Toledo, Hermenegildo rebelde desafortunado, Recaredo depositário e instrumento do clericalismo hispano-romano. (FONTAINE, 1967, p. 88-89)

Contemporâneo dos fatos, o cronista de Gerona designaria Hermenegildo como "tirano"; algumas décadas mais tarde, Isidoro de Sevilha (aprox. 532-636) faria o mesmo (BICL. Chron. aprox. 579 e 582; ISID. HG 49).$^{2}$ De fato, o problema se apresenta de forma bastante intrincada. Por um lado, esse dois cronistas ibéricos, apesar de católicos, não se posicionam contra Leovigildo. O 3Toledo ${ }^{3}$ de 589 que realizou a conversão oficial do reino, apesar de contar entre seus principais dirigens o irmão mais velho de Isidoro, Leandro, bispo de Sevilha e inspirador de Hermenegildo, não 
menciona esse último em nenhum momento. No século VII, o anônimo cronista de Mérida, apesar de se referir a Leovigildo como "o selvagem e cruel rei dos visigodos" (VSPE, 5.4.2. ep.) ${ }^{4}$, também se cala sobre seu filho rebelde. Na Gália franca, endêmica inimiga do reino de Toledo, Gregório de Tours afirma que se tratava de uma rebelião católica e que, quando o rei tomou ciência da conversão de seu filho, imediatamente "buscou pretextos para enfrentá-lo" como um "martir" (THOMPSON, 1971, p. 92-93), que também conta apenas com um breve apoio dos enclaves bizantinos da Hispânia Meridional (FONTAINE, 1967, p. 100 e no18).

De fato, a questão é de grande complexidade. Dela, nos preocupa o dado religioso. Não deixa de chamar a atenção o fato de que a aristocracia hispano-romana, predominantemente católica, não tivesse se posicionado ao lado de Hermenegildo ou dos enclaves bizantinos católicos. J. Fontaine, em sua segunda tríade acima mencionada, cita Recaredo como "depositário e instrumento do clericalismo hispano-romano". Ao menos entre as elites peninsulares, aparentemente, manifestava-se uma "consciência nacional" (DÍAZ Y DÍAZ, 1991, v.1, p. 7). ${ }^{6}$ Mas um certo regionalismo e irredentismo dessa aristocracia, e não apenas a peninsular, já havia sido apontado para uma época anterior com relação ao Império Romano. No século V, ele seria registrado pelos relatos de Paulo Orósio e Hidácio, ambos católicos e de origem peninsular. O primeiro diria que a Hispânia fora invadida, "sofrera mortes e devastações; mas nada padecera nas mãos dos bárbaros, nem mesmo naquele biênio no qual a espada dos inimigos se enfurecera, que antes já não houvesse sofrido durante duzentos anos por parte dos romanos(...)" (OROS. Historiarum adversum paganos VII.41). ${ }^{7} \mathrm{O}$ segundo comentaria que "quando arrefecem os excessos dos bárbaros e a peste provoca uma dor menor, as riquezas e as provisões estocadas nas cidades são extorquidas pelo tirânico coletor de impostos e esgotadas pelos soldados" (HYD. Chron. CCLXXXXVII.48). ${ }^{8}$ Abria-se a possibilidade para a articulação de um novo conceito: gens et patria gothorum (4Toledo,75 - 633) ${ }^{9}$. Ele passaria a reunir os elementos sociais e territoriais de raízes romanas sob a única denominação étnica dos godos (DÍAZ Y DÍAZ, 1991, p. 7). Como elemento coesivo, essa nova aristocracia teria como denominador comum a unidade religiosa. A tentativa de Leovigildo fracassara por tentar impô-la através do arianismo; Recaredo corrigiria o rumo realizando o ideal de unidade através do catolicismo HILLGARTH, 1961, p. 34). Seria, pois, o cristianismo católico o elemento cimentador da unidade desse novo grupo dirigente. ${ }^{10}$

Ruy de O. Andrade Filho. O REINO VISIGOdo: CATOLICISMO E PERMANÊNCIAS PAGÃs 
No presente artigo, tentaremos reconstituir, sob o ponto de vista da Nova História Cultural, alguns dos problemas suscitados pela cristianização/conversão da Península Ibérica da Antigüidade Tardia, base em que se desenvolveria o reino visigodo de Toledo. Por cristianização, estaremos entendendo os sinais exteriores da presença da nova fé. Por conversão, procurar rastrear até ponto, a pregação, as construções eclesiásticas, as medidas legislativas civis e canônicas, os novos rituais, a elaboração de um conjunto de comportamentos cristãos tinham, de fato, passado a integrar o cotidiano dos homens, seu modo de vida, sua visão de mundo, em fim, sua religiosidade (ANDRADE FILHO, 2005, p. 91-101). Tal como nos lembram Isidoro e Bráulio de Saragoça,

Cristão, segundo deixa ver sua etimologia, deriva de unção, ou talvez do nome de seu fundador e criador, no sentido de que os cristãos recebem seu nome de Cristo, da mesma forma que os judeus o tomaram de Judá. Isto é, aplica-se aos seguidores um nome derivado de seu mestre. Noutro tempo, os judeus, como injúria, chamavam 'nazarenos' aos cristãos, devido ao fato de que nosso Senhor e Salvador foi conhecido como 'Nazareno' na aldeia desse nome, na região da Galiléia. Que ninguém se glorifique de ter o nome sem praticar os atos do cristão (ISID. Etym. VII.14.1-3).

Da mesma forma que a qualidade de um objeto moldado não consiste somente na perfeição do metal, se a mão do artífice, ordenando suas partes, não lhe aplica uma conveniente beleza, assim a fé, se não está acompanhada de nenhuma obra, não somente se manifesta sem beleza, mas morta; por isso, sem dúvida, a luz da fé, quando não é alimentada por boas obras, extingue-se em seguida. (ILD. De itinere deserti 83). ${ }^{11}$

Até que ponto o cristianismo estaria verdadeiramente arraigado, enquanto convicção religiosa, em meio às elites ibéricas? Mais que isso, sem estarmos dotados de uma rigorosa distinção entre poderosos e humildes, leigos e eclesiásticos, mas utilizando a idéia de que existe entre eles um denominador comum, uma "cultura intermediária", situada na convergência dos dados provenientes dos polos culturais (FRANCO JR., 1996, p. 36-38), em que medida podemos entender a conversão oficial do reino refletindo também a da população? Esse processo de cristianização, necessário para a coesão do grupo dirigente e coerência das estruturas do reino de Toledo implicaria, de fato, uma verdadeira conversão da população peninsular? O exemplo, dentre outros, do crescimento das fundações monásticas ou das construções de igrejas rurais, algumas inclusive de fundação privada ("igrejas próprias”), que podem ser tidos - até certo ponto, visto que muitas destas 
construções tinham objetivos fiscais ou econômicos, dentre outros - como um sintoma de uma cristianização podem, em contrapartida, serem vistos igualmente como uma prova de uma efetiva conversão de seus construtores e frequentadores? Como já se disse, apesar de suas "superstições", os camponeses não duvidavam do fato de ser cristãos (SCHMITT, 1976, p. 945). Todavia, não devemos nos esquecer, como apontaremos adiante, que o critério "oficial" da conversão cristã implicava uma completa transformação moral e espiritual. Integrava, pois, uma mutação interna, uma mudança de convicções íntimas e, consequentemente, individualizadas, afeitas mais ao campo da religiosidade. Essa última, de fontes profundas e variadas, coincide com a condição existencial do homem, implicando a questão do seu próprio destino, situando-se na estrutura mental, da qual ela faz parte (GIORDANO, 1983, p. 12; FRANCO JR., 1990, p. 39).

Uma abordagem da Hispânia na Antigüidade Tardia requer, como noutros períodos de sua história, um cuidado acentuado para que não se tenda a generalizar características regionais. De fato, são grandes os contrastes. Uma consideração preliminar já nos indica para a época romana, a fraca colonização do norte e noroeste. O sul e o Levante, ao contrário, mostram-se plenos de vida urbana e comercial. Somente com o início da época imperial é que se adotaria o uso do singular Hispania para designá-la (TEILLET, 1984, p. 11-12 e no 54). Nesta mesma época, o geógrafo Estrabão comentaria: “os habitantes do litoral do Mare Nostrum diferenciam-se muito das populações celtas do interior que, por sua maior pobreza e distanciamento, continuavam vivendo em aldeias e não em cidades" (Apud: MANGAS, 1982, v. 1, p. 282). Partindo-se dessas constatações, deparamo-nos, grosso modo, com pelo menos duas Hispânias. Uma Meridional, em que predominava o modo de vida mediterrânico; outra Setentrional, na qual a sobrevivência dos modos de vida e de organizações sociais pré-romanas parecem ter sido particularmente mais resistentes à integração com as formas romanas (BARBERO; VIGIL, 1974, p. 14-104, 139-195; PRIETO ARCINIEGA, 1981, p. 67-77).

Teríamos assim que considerar essas bases para a propagação do cristianismo. Mas suas origens ali ainda permanecem desconhecidas. ${ }^{12}$ Acredita-se que na Península, como noutras partes, as comunidades primitivas existissem apenas nas cidades, reunindo especialmente escravos, libertos, comerciantes e artesãos, com a maioria de seus membros sendo procedentes, em princípio, das regiões orientais do Mediterrâneo e 
estreitamente relacionados com as comunidades judáicas, que também são pouco conhecidas quanto ao seu número, densidade ou localização, mas que seriam fundamentais para sua propagação, na medida em que "era nelas que se realizava sempre a primeira semeadura apostólica” (DÍAZ Y DÍAZ, 1966, p. 9; VIGIL, CABO, 1978, p. 394-395). Seria apenas com as perseguições de meados do século III que surgiriam os primeiros informes seguros sobre comunidades cristãs em Mérida, Astorga-Leão e Saragoça. Pouco depois, as atas dos mártires e as obras de Prudêncio (348-410) acrescentariam cidades como Tarragona, Calahorra, Barcelona, Valência, Sevilha e Córdova, dentre outras (VIGIL, CABO, 1978, p. 396).

De fins do século III e inícios do IV, as atas do concílio de Elvira listariam como cristãos desde membros das oligarquias municipais até escravos e prostitutas, permitindo entrever uma Igreja ativa e com uma hierarquia já esboçada pelos bispos, presbíteros e diáconos (Elvira 2,8,11,18,19,33,44,56,80 ep.). A partir desse momento, algumas análises historiográficas consideram que a Península, à par das exceções e das variantes regionais, contava com um adiantado processo de cristianização, uma boa organização eclesiástica e um significativo número de cristãos urbanos (GONZÁLEZ, 1979, p. 663-664); ou que, nesse momento, "o cristianismo já havia invadido toda a Península" (ECHEGARRAY, 1966, p. 216). ${ }^{13}$ O paganismo, apesar de não estar eliminado e se encontrar muito enraizado em certas regiões no norte, teria, no entanto, "perdido a sua importância", sendo uma prova disto o fato de que "todos os homens ilustres conhecidos são cristãos (...)" (SOTOMAYOR Y MURO, 1987, p.171). O problema maior, pois, não seria tanto o do paganismo declarado, mas o da permanência, especialmente nos meios rurais e, mais especificamente, na Hispânia Meridional, de cultos residuais e práticas supersticiosas que seriam difíceis de desenraizar (ORLANDIS, 1977, p.21).

Significativamente, é também a partir da segunda metade do século IV, que a palavra "pagão" adquiriria um peculiar sentido religioso. Apesar do termo clássico paganus já ser utilizado pelos cristãos no sentido de "não batizado", São Jerônimo (aprox. 342-420), na Vulgata, prefere termos como gentes, gentiles, nationes, ethnici. O termo gens (raça ou família) teria em seu plural, gentes, o significado de bárbaros. Sua utilização, sobretudo na segunda forma, é frequente na Bíblia, coincidindo em muitos locais com o significado do termo do latim clássico. Noutras partes, aparece desenvolvendo uma acepção nova, próprias do Antigo e do Novo Testamentos e do latim cristão, onde gentios ou pagãos designavam aqueles que não adoravam Yahvéh ou Cristo (GARCÍA DE LA FUENTE, 1991, p. 177-178). 
Etimologicamente, significava aldeão, camponês, habitante de um povoado ou aldeia. Nos inícios do século V, Paulo Orósio deixaria clara a conotação religiosa do termo: "aqueles que, por serem estranhos à cidade de Deus, das encruzilhadas, dos lugares agrestes e das aldeias de onde procedem, se lhes dá o nome de pagãos ou gentios (...)" (OROS. Historiarum adversum paganos, prologus), sentido que seria retomado pelos concílios de Toledo e no texto isidoriano ${ }^{14}$. Desde a segunda metade do século IV, o contraste entre cidade e campo, entre o aldeão rústico e aquele que morava próximo à cidade, revestia-se de um sentido particular no plano religioso (ORLANDIS, 1988, p.32. ROBLIN, 1953, p. 173-183). ${ }^{15}$

Não por acaso, data também do século IV a adoção definitiva pelo cristianismo do sentido negativo de superstitio, que nada mais era senão o paganismo sobrevivendo no seu interior. Religio, procedendo etmologicamente de re-ligare, seria o culto do verdadeiro Deus, enquanto superstitio seria o do falso e, logo, associada nos textos de Santo Agostinho, à demonologia, à sedução diabólica, causa primeira pela qual o homem caíra em pecado. Assim, observavam-se enquanto superstições a maioria das práticas pagãs, às quais os autores cristãos designavam genericamente como idolatria e que, para além do culto aos ídolos propriamente dito, incluía também a adoração da criatura (homem ou demônio), de elementos da natureza ou um objeto (SCHMITT, 1988, p. 425-429). Pelas superstições dos gentios, toda a terra havia sido convertida numa selva, "porque todos os deuses das gentes são demônios" (AUG. Enarrationum in Psalmos 95.5-6). ${ }^{16}$ Supersticiosos, diria Isidoro, eram "aqueles que rezavam ou ofereciam sacrifícios diários para que seus filhos lhe sobrevivessem". Nos concílios do reino de Toledo, o termo seria empregado para os hereges, os judeus e o erro diabólico. ${ }^{17}$

Realizado numa de suas áreas mais romanizadas, o concílio de Elvira nos revela através de suas atas uma Hispânia onde encontramos cristãos que, simultaneamente, são sacerdotes pagãos; temores quanto à possibilidade de que alguém pudesse matar por meios de malefícios; receios quanto ao acendimento de velas nos cemitérios durante o dia, "para não molestar os espíritos dos justos"; pedidos para que as matronas ou seus maridos não dessem "suas vestimentas para adorno de procissões mundanas"; a proibição de mulheres velarem nos cemitérios porque, "sob o pretexto da oração são cometidos de forma oculta graves delitos"; exortação para que os fiéis não fossem "ao capitólio para oferecer sacrifícios" e que os senhores coibissem a prática de idolatria entre seus servos; reclamam da ausência dos fiéis "habitantes da cidade que não comparecem à igreja durante três domingos" (Elvira, 2-4;6;34;58;35;59;41;21,46 ep. respectivamente). ${ }^{18}$ 
Assim, para aquela Hispânia que já havia sido "tomada pelo cristianismo", os cânones de Elvira nos surpreendem com práticas muito diversas daquelas da simples idolatria em sentido estrito, do homicídio ou da fornicação, ítens que são apontados como suas principais preocupações. $\mathrm{O}$ acendimento de velas estava ligado a práticas pagãs ou supersticiosas e a razão de sua proibição ainda é bastante questionada (RAMOS-LISSÓN, 1986, p. 39). Talvez pudesse estar conectada com os cultos ao ar livre ou cerimônias pagãs comemoravadas diariamente ao amanhecer, em homenagem ao sol. (GIORDANO, 1983, p. 89). Mas, a obtenção de mortes por meio de malefícios, de magia negra, não eram exclusividades hispânicas. Santo Agostinho nos narra a história de uma viúva da Capadócia que lançara no batistério uma maldição contra seus dez filhos que, afetados por ela, tiveram que percorrer o mundo em busca de uma cura (AUG. De civitate Dei XXII.8.22). ${ }^{19}$ "As pessoas do campo repetiam blasfêmias e maldições enquanto semeavam seus campos, acreditando que suas imprecações teriam um efeito apotropáico, protegendo sua colheita de pragas demoníacas(...)" (CHADWICK, 1978, p. 78). Uma lei imperial, de meados do século IV proibia expressamente orações malígnas noturnas, ao lado de fórmulas mágicas ou sacrifícios sinistros (C.Th. IX.16.7). ${ }^{20}$ Mesmo que não existissem razões claras para se crer que somente mulheres praticassem magia, os autores pagãos e cristãos estabeleciam essa relação. É provavel que esse relacionamento estivesse ligado ao fato de, quase sempre, elas terem sido responsabilizadas pela transmissão dos valores tradicionais religiosos através da educação. Ela deteria "os segredos mágicos da cura, da defesa e da fecundação, consolidados pelos gestos, fórmulas, técnicas de recolha de plantas, ervas e pedras" (NOLA, 1987, v.12, p. 129-130). Ou ainda que elas teriam sido ensinadas pelos anjos caídos, na medida em que elas seriam mais "vulneráveis a esses espíritos do mal" (KIECKHEFER, 1992, p.48; CHADWICK, 1978, p.189). Apesar dessas práticas não estarem restritas a um único ambiente ou região, os cânones de Elvira nos surpreendem com um mundo de magia, bruxaria, superstições, paganismo dentre outras, que parece bastante distinto de uma Espanha "cristianizada" ou para a qual os "resquícios pagãos" tivessem "perdido a importância”. Por outro lado, a alusão aos nomes de personagens importantes, "dados pela Igreja hispânica ao conjunto da história da Igreja, não é um argumento válido de nenhuma forma. Numa população de sete milhões de habitantes, isso seria demasiadamente escasso" (ARCE, 1988, p. 127). Tratava-se, pois, de um concílio de caráter eminentemente disciplinar (RAMOS-LISSÓN, 1986, p. 23), prescrevendo normas de conduta tanto para clérigos como para fiéis dentro de um ambiente pagão. 
O concílio contara com a representação de 37 igrejas, cuja distribuição apontava 23 na Bética, 8 na Cartaginense, 3 na Lusitânia, 2 na Tarraconense e 1 na Galiza. Com exceção de Leão e de Braga, é significativa a ausência dos representantes do norte e noroeste da Península. ${ }^{21}$ Fora da Bética, os cristãos se concentravam nas comunidades privilegiadas, mais romanizadas. $\mathrm{Na}$ Gália, o concílio de Arles também indicaria uma maior concentração no sudoeste, na atual Provença (Arles, subscriptiones - 314, p. 14-22, CONCILIA GALLIAE - 314-506), com as demais regiões contando com comunidades mais desenvolvidas apenas nas cidades mais importantes, situação que se repetia para o norte da Itália. Desse forma, no Ocidente, o contraste ficaria apenas por conta da Itália peninsular (de Ravena a Nápolis) e do nordeste do Magreb, onde seriam observadas notáveis densidades. Na primeira, em meados do século III, o Papa Cornélio reuniria num sínodo cerca de 60 bispos; na segunda, na mesma época Cipriano de Cartago conseguiria reunir 87 bispos africanos (MARROU, 1964, p. 432 e 263; ORLANDIS, 1988, p. 26). Na Espanha, pois, como noutros pontos do Ocidente europeu, o cristianismo apenas avançava (ANDRADE FILHO, 2005, p. 359-371; ANDRADE FILHO, 2012, p. 71-99).

Elvira também nos chama a atenção pelo tom nítidamente urbano de seus cânones. Sintomaticamente, é nesse momento que o termo pagão adquire um acento religioso. É significativo, na medida em que trás à tona, a existência de um outro paganismo, diverso daquele encontrado nas cidades. A emergência do mundo rural como grupo de pressão cultural evidenciava aquele paganismo das crenças tradicionais, aquelas de uma muito longa duração, diferente daquele da religião oficial greco-romana que era mais evolutiva; mesmo Santo Agostinho, atento à distinção entre urbanitas e rusticitas "nos aspectos sociais das mentalidades, das crenças e dos comportamentos (...) consegue sempre essa distinção” (LE GOFF, 1979, p. 208; 212 e no17). Entendido como um conjunto de crenças e práticas arcaizantes, o termo folclore designaria para a Igreja medieval os resquícios de um passado distante correspondendo, de certa forma, ao uso que ela dava à superstição. E era justamente entre os mais simples que a religiosidade e a espiritualidade se mostravam mais vivas. Tal como a cultura antiga, o cristianismo também se mostraria, inicialmente, como um "fenômeno essencialmente urbano" (MARROU, 1964, p.332).

Mas era justamente esse o mundo que se encontrava em declínio. Na. medida em que evoluíam as vicissitudes estruturais do Baixo Império, diluíam-se os segmentos sociais citadinos que tinham apoiado os seus primeiros avanços (ANDRADE FILHO, 2009, p. 136-146). Logo, mais 
que contra a religião oficial romana, o cristianismo se veria às voltas com o gradativo crescimento em importância dos meios rurais, pouco ou nada tocados pela cultura antiga. Ali, ao menos na essência de sua vida religiosa, mantinham-se despertas as velhas crenças ancestrais, "contra as quais lutavam os missionários encontrados em ação nas últimas décadas do século IV” (MARROU, 1964, p. 332). Por vezes completamente alheios aos avanços cristãos, os meios rurais se apresentavam como um desafio. Havia o tradicionalismo da mentalidade camponesa, e uma complexa mescla de usos e costumes que, em diversos momentos, remontavam ao substrato celta, manifestando-se como claros obstáculos às transformações. Para além da religiosidade tradicional, que agregava os possuidores de uma formação clássica, o verdadeiro inimigo cristão seria esse velho fundo de crenças tradicionais, que ressurgiam das ruínas do paganismo romano e que "tanto poderiam fundir-se sem desaparecer no substrato do psiquismo coletivo, como poderiam emergir, incorporando-se ao cristianismo e deformando-o com seu folclore" (LE GOFF, 1981, v. 7, T. I, p. 61).

O declínio do mundo urbano, a diluição dos segmentos sociais mais confiáveis do cristianismo, a emergência do mundo rural e de seu folclore além da existência ainda de uma certa oscilação quanto aos dogmas da nova fé, abriam espaços para os sincretismos,

processo contra-aculturativo implicando manipulações de mitos, empréstimos de ritos, associação de símbolos, às vezes inversão semântica da mensagem crística. Não se trata portanto de aculturação (isto é, assimilação e/ou imposição cultural), cujos estudos tendem a explicar as trocas do ponto de vista de apenas uma das culturas envolvidas no processo (FRANCO Jr., 1996, p. 51).

Depois, qualquer que tenha sido a origem do cristianismo ibérico ele, tal como a romanização, teria que interagir com seus regionalismos, com as suas gentes. Estas últimas criariam problemas e situações particulares, das quais decorreriam soluções e expedientes específicos. Roma havia se mostrado tolerante para com as religiões nativas (BLÁZQUEZ, p. 437) e, se por um lado, favorecera o obscurecimento de algumas religiões peninsulares em áreas como a Bética e o Levante, pouco ou nada tinha alterado o panorama da Hispânia Setentrional, especialmente nos meios rurais. Por outro lado, se elementos como o dinamismo da urbanização e do comércio, dentre outros, favoreciam o proselitismo, mesmo supondo uma colheita farta, nem toda semeadura seria cristã. No decurso do primeiro milênio a.C., a bacia mediterrânea vivenciaria "uma espécie de koiné religiosa, com o panteão hispâno e o caráter de seus 
deuses sendo bastante parecidos com os da Gália, o que não é de surpreender dado o denominador comum céltico sobre o qual se daria posteriormente a romanização e a cristianização (FRANCO Jr., 1990, p. 37). Assim, os vários deuses conhecidos para a Península na Antigüidade corresponderiam a blocos religiosos: o indígena, o romano e o oriental, sendo que, dentro desse último, alocava-se o cristianismo (MANGAS, 1982, v.1, p. 402).

Por outro lado, muito do sucesso da pregação inicial da nova fé, também se devia à inexistência de um arcabouço doutrinal preciso. Seu caráter, até então essencialmente urbano, possibilitava uma observação mais estrita dos fiéis das comunidades. Discórdias internas já tinham sido previstas "para que se mostrem manifestos entre vós aqueles que têm uma virtude comprovada"; falsos mestres "trarão seitas perniciosas" (1Cor 11.19; 2Pd 2.1). A heresia figuraria dentre "os fatores do impulso doutrinal recebido pelo cristianismo” (SIMON; BENOIT, 1987, p. 149). É também no século IV que haeresis (escolha, opinião, sistema, doutrina, seita) traduzido como "seita" ou "discórdia", ganharia o significado dogmático que lhe imprimiram os autores eclesiásticos, época em que seria íntimamente associado a schisma (separação, divisão) (GARCÍA DE LA FUENTE, 1991, p. 156). Apesar dessa imprecisão, desde o século III a palavra designava uma divergência doutrinal, uma inovação arbitrária. Nos fins do século IV, ela seria entendida como "aqueles que pretendem confessar a verdadeira fé, mas se separam dos nossos bispos legítimos e celebram reuniões entre eles". Todavia, já nos inícios do século V, Santo Agostinho comentaria a respeito da inexistência de uma definição taxativa de heresia e sobre as dificuldades que implicavam sua definição (ESCRIBANO, 1990, p.151-153).

Estabeleceu-se também uma certa relação entre o estrangeiro e a heresia, precrevendo-se normas para a aceitação dos "cristãos que se convertessem de qualquer heresia”, proibindo-se que eles fossem ordenados; também que os viajantes fossem obrigados a apresentar cartas de comunhão, para que pudessem ser "examinados a respeito de sua fé" (Elvira, 51 e 58). Em fins do século IV, essas incertezas e inseguranças seriam apresentadas na abertura de um concílio: "por que cada um de nós começou a trabalhar de distintas formas em nossas igrejas, originaram-se os escândalos que quase chegaram a verdadeiros cismas(...)". Também um contrapondo mais claro entre as comunidades urbanas e rurais, determinando-se que "qualquer clérigo consagrado à Igreja, encontrando-se na cidade ou noutro local em que exista igreja, num castelo, aldeia ou fazenda e não comparecer todos os dias ao sacrifício do templo, não deveria mais ser tido como clérigo(...)" (1Toledo,5). Tanto a Lex Visigothorum como os concílios hispânicos posteriores à conversão 
de Recaredo tratam das heresias com brevidade ${ }^{22}$. Aparentemente, elas não teriam sido um problema que pudesse preocupar a monarquia e a Igreja da época católica (KING, 1981, p. 154-155; GONZÁLEZ, 1979, p. 683ss).

Mas essas incertezas quanto à ortodoxia, o empobrecimento econômico e demográfico dos centros urbanos, o crescimento em importância dos meios rurais, tal como o vazio político deixado pelo império desde inícios do século IV, abririam caminhos tanto para novas formas e estruturas de poder quanto para a expansão do cristianismo. A Igreja, à medida em que se secularizava, tendia a modelar sua organização de acordo com a estatal, transformando-se num dos ramos da administração pública; paralelamente, "o episcopado começaria a se identificar com os grupos sociais dirigentes", logo transformando o cargo "num privilégio econômico" (VIGIL; CABO, 1978, p.398; BARBERO, 1986, p. 92-94). Especialmente nas províncias ocidentais, a antiga aristocracia se rearticularia. Se até fins do século IV a nova fé se encontrava mais difundida entre os segmentos médios e inferiores urbanos e quase não atingia a aristocracia e a massa camponesa (JONES, 1989, p. 34-36; LE GOFF, 1979, p. 209), em fins do século IV e inícios do V essa tendência se inverteria, com as camadas superiores tendendo a monopolizar "tudo o que restava de vida civilizada fora da Igreja e também, cada vez mais, fariam parte da própria Igreja” (MOMIGLIANO, 1989, p. 23). A durabilidade da estrutura de poder do episcopado na época visigoda se explica, em grande parte, pelo assalto dos epígonos da poderosa aristocracia hispano-romana aos cargos da hierarquia eclesiástica (GARCÍA MORENO, 1990, p. 231). Sintomaticamente, nesse momento, desenvolve-se na Hispânia uma heresia original: o priscilianismo, que teria forjado na Espanha, "um dogma que é uma mescla da heresia dos gnósticos e dos maniqueístas” (ISID. Etym VIII.5.54).

Embora a afirmação isidoriana seja clara, tanto a figura de Prisciliano como o movimento religioso a que deu origem foram e são extremamente controversos, ainda sendo posta em pauta muitas dúvidas quanto à sua "efetiva heterodoxia" (MATTOSO, 1993, p. 291). De forma velada, ele seria considerado por um concílio em 380 (1Saragoça - 380). Cinco anos mais tarde, Prisciliano seria executado em Tréveris, pelo braço secular. Contudo, o movimento a que dera origem seria tema explícito de outros concílios, um deles ao redor de 400, (1Toledo - 400), logo após a sua execução. Dentro do contexto em que emergiu, são grandes as possibilidades de interpretação do movimento que leva seu nome. Elas variam desde a idéia de que se trata de "uma reação essencialmente religiosa” (RAMOS-LISSÓN, 1986, p. 67; McKENNA, 1938, p. 50ss; BARBERO, 1986, p. 94), àquelas que buscam ressaltar o caráter social dos cismas e heresias dos primeiros séculos cristãos, (BARBERO, 1986, p. 97 
ep; THOMPSON, 1952, p. 12-21), dentre outras. De tendências populistas, rurais e muitas vezes esotéricas, rapidamente lhe seria imputado um caráter mágico e imoral. Num momento de definições para a nova fé, tais acusações sugeriam uma solução que, se não era de definição simples, pelo menos, na prática, seria momentaneamente veloz e eficaz (SULP.SEV. Chron. II.46.1,5; OROS. Commonitorium 2; HYD. Chron. CCLXXXXI.13b. CHADWICK, 1978, p. 137; 44-45; 135-137; 253; 270-273 ep). ${ }^{23}$

Mas a heresia que Prisciliano havia propagado "não somente não foi reprimida mas, reafirmando-se, propagou-se mais extensamente. Pois seus seguidores, que antes o honravam como a um santo, depois começaram a venerá-lo como um martir" (SULP.SEV. Chron. II.51.7). No século V, seu caráter rural, popular e galego seria acentuado, contando com a adesão de grande parte do episcopado regional (MATTOSO, 1993, p. 291, 287ss; ORLANDIS, 1991, v. 1, p. 434). No que concerne à hierarquia episcopal, essa situação seria "revertida no século seguinte" mas, fora dela ainda se alastrava "a perniciosa heresia", condenada junto a outras práticas em 561. Nos inícios do século VII ela seria, aparentemente, apenas uma lembrança. Todavia, nesse último século, ela ainda mereceria a recomendação de Bráulio de Saragoça a Fructuoso de Braga: "De todas as formas, tenha cuidado com a doutrina envenenada de Prisciliano, que não faz muito tempo floresceu por essa região..." (BRAUL. Ep.44).

A primeira reação ao movimento teria partido da Hispânia Meridional e, nela, residiriam seus principais adversários. De forma inversa, as comunidades da àrea Setentrional se mostrariam mais receptivas, inclusive nos meios hierárquicos. Na geografia da expansão priscilianista e na localização de seus maiores opositores, desenhava-se novamente as Hispânias apontadas anteriormente por Estrabão. Mais que autênticas divergências dogmáticas, a questão priscilianista parece apontar para um conflito de interesses, de rivalidades entre indivíduos da aristocracia e setores da Igreja hispânica. "Por outro lado, a capacidade atribuída ao bispo para distinguir a heresia da ortodoxia para seus concidadãos e fiéis, comprova a forte identificação entre o cristianismo, a hierarquia local e o mundo urbano" (GARCÍA MORENO, 1990, p. 233-234; 237).

A progressiva confusão entre as funções militares, fiscais públicas e privadas, favorecia o crescimento dos vínculos particulares de dependência pessoal, social e economicamente. Esse processo ainda é difícil de ser matizado para a Hispânia mas, sem dúvida, como noutras partes, alargaria o fosso entre honestiores e humiliores. Restringia-se a liberdade dos segundos, ampliando-se o número de precaristas, encomendados e arrendatários de 
terras alheias e o poderio dos detentores legais dessas, laicos ou eclesiásticos. De forma geral, tais possessores impediam a encomendação desses colonos a outros senhores, convertendo-se em legítimos patronos. Acolhendo camponeses de situações diversas ou dando-lhes a proteção em troca da transferência de suas propriedades, principiavam a união entre as figuras do dominus - relação econômica entre o detentor e o colono -- e do patro$n u s$ - relação de proteção cedida em troca de prestações de índole diversa e, portanto, extra-econômicas - através do patrocinium (BARBERO; VIGIL, 1978, p. 22-23 et passim). Assistia-se aos progressos da grande propriedade como unidade de produção, exploradas sob as formas senhoriais desenvolvidas no Baixo Império. A ruralização se fazia acompanhar pela tendência à concentração fundiária que, iniciada pela Igreja e pela aristocracia hispano-romana, e que teria continuidade em meio ao reino de Toledo. Os bispados se organizariam de forma semelhante aos grandes domínios, inserindo-se em meio às relações de dependência pessoal. Logo seriam tomadas medidas para a manutenção do contínuo crescimento do patrimônio eclesiástico, fornecendo-lhe um caráter inalienável: a Igreja era a "patrona que nunca morre". Disfrutando de amplos poderes políticos, econômicos e, por vezes, militares, ela exerceria forte atração em meio à aristocracia, grupo do qual acabaria por se tornar "porta-voz junto aos soberanos de Toledo" (4Toledo,70 ep.; BARBERO; VIGIL, 1978, p. 53-104; GARCÍA DE CORTÁZAR, 1983, p. 34). A importância do cargo episcopal ficaria ainda mais evidenciada, dentre otras coisas, pela inclusão dos bispos entre os eleitores do monarca, dando a ele uma nova dimensão política, despertando ainda ainda mais as ambições aristocráticas, tendo como sequela a sua "crescente 'senhoralização"' (ORLANDIS, 1991, v.1, p. 478), a ponto de serem criticados aqueles que o buscavam para "tornarem-se ricos e receberem honras (...) desejando apenas a dignidade do cargo" (ISID. Sentent. III,34,5). ${ }^{24}$ Tais argumentos não intencionam negar a importância de outros aspectos que promoviam as conversões ao cristianismo. Todavia, concordamos com a idéia de que, para além dos motivos, a busca das causas dessa viragem "deve insistir em dois tipos de mediação: as sociais e as políticas” (LE GOFF, 1981, v. 7, T. I, p. 67).

Da mesma forma, essa interpenetração também se operava entre os humildes. A bipolarização social apontada para as cidades se repetiria nos meios rurais. Se, como parece, a montagem do reino de Toledo não implicaria o desaparecimento dos indivíduos livres não privilegiados ou da pequena e média propriedades (TORRES LÓPEZ, 1976, p. 201; VALDEAVELLANO, 1982, p. 181), por outro lado, não se pode negar que cada vez mais, tanto os ingenui minores como suas posses iam se tornando dependentes em 
diversos graus, seguindo a lógica própria de todas as transformações que se operavam e então se cristalizavam. Tal fenômeno ocorria em função de um duplo movimento: de cima para baixo, com o seniores buscando uma clientela mais ampla, que lhes assegurasse a posse de seus domínios e que lhes desse parcelas do poder que a monarquia não conseguia mais manter; de baixo para cima com os ingenui minores sentindo que a liberdade sem os privilégios e isenções dos maiores loci de nada valia, e que o melhor caminho para a segurança e a sobrevivência era se encomendarem àqueles (TORRES LÓPEZ, 1976, p. 211ss; BARBERO; VIGIL, 1978, p. 22-23 ep). Com grande facilidade, os potentes e, com maior razão, aqueles que ocupavam postos administrativos no reino, não apenas poderiam exercer pressões para que eles se colocassem sob seu patrocínio, mas também lhes oferecer certas vantagens, tais como defendê-los de terceiros, incluindo-se aí as ações do poder central (GARCÍA MORENO, 1982, v.2, p.396).

Os visigodos se inseririam em meio a esse processo sem grandes problemas. Suas estruturas tinham passado por diversas transformações e adaptações dentro do período que se extende entre as grandes migrações e o seu definitivo estabelecimento nos territórios ibéricos. A sippe, grupo familiar ou gentílico agnático, constituindo uma unidade econômico-jurídica e, às vezes, militar, debilitara-se diante do fortalecimento da monarquia. As constantes situações de guerra ampliaram entre eles o costume da comitiva que, juntamente com o acesso a propriedade, especialmente de bens imóveis, dentre outras razões, contribuiriam decisivamente para a destruição da antiga sociedade tribal, criando os fundamentos de uma nova organização social (SÁNCHEZ-ALBORNOZ, 1974, p. 9; THOMPSON, 1966, p. 55). -À parentela também se sobreporiam os vínculos privados de dependência pessoal. As fórmulas romanas foram adotadas de forma progressiva, convertendo os membros mais pobres da população em camponeses dependentes. O crescimento desses vínculos não encontraria freio no fortalecimento da Monarquia, que os estenderia ao plano político (BARBERO; VIGIL, 1978, p. 35-39, 25-26, 105ss). Tendo-se em conta que o poder decisório dependia da extensão fundiária e, especialmente, do número de dependentes, em diversas ocasiões o potentior estaria "numa situação de fato muito sólida para gozar de privilégios que de iure não possuía" (KING, 1981, p. 214). Fortalecia-se assim a causa dos regionalismos e, paralelamente, a interpenetração horizontal entre as aristocracias visigoda e hispano-romana. Nesse aspecto, a Igreja já tinha se mostrado como um importante meio de integração, uma vez que, desde o início, não haviam restrições étnicas ou sociais para se fazer parte dos quadros eclesiásticos ${ }^{25}$. De forma sintomática, em fins do século 
VI Leovigildo aboliria a antiga proibição de casamentos mistos (LV III,1,1). Reconheceria, dessa forma, a constituição de uma nova aristocracia, cuja consolidação ideológica seria dada pela cristianização oficial do reino com Recaredo (GARCÍA MORENO, v.1, p. 325-326).

A partir da conversão, em termos religiosos, para além da questão do priscilianismo tardio, menciona-se a existência de uma pequena, mas considerável comunidade judáica, além das sobrevivências pagãs, resíduos que teriam subsistido entre as populações de certas áreas da Península, mais arraigado em determinadas regiões periféricas e montanhosas, escassamente romanizadas (ORLANDIS, 1991, v.1, p. 433-434, 446-448). Data de meados do século VI o elogio feito a Toribius de Palência, que com diligência e cuidado, tinha arrancado dalí "o erro da idolatria e a vergonhosa seita priscilianista" (2Toledo, p. 50). Muitos santuários pagãos tinham se transformado em igrejas, tal como na Gália e como o templo do deus Endovellico, próximo a Évora, virtualmente substituído pelo Arcanjo São Miguel. Mas o processo de conversão dos pagãos foi lento (BLÁZQUEZ, 1975, p. 93-95; ARCE, 1988, p. 123-130; GONZÁLEZ ECHEGARRAY, 1966, p. 115ss; HILLGARTH, 1980, p. 15ss). Na época em que Toribius era elogiado, Martinho de Braga ainda combatia diversas práticas pagãs no seu De correctione rusticorum: acender velas junto a pedras, àrvores, fontes e encruzilhadas; práticas adivinhatórias, augúrios, festas das Calendas e Vulcanais, observação do pé com o qual vai se pisar; mulheres que invocavam Minerva enquanto tecem; colheita de ervas de forma supersticiosa para realização encantamentos, invocando-se nomes demoníacos... (MART.BRAC. De corretione rusticorum 16). ${ }^{26}$ Palavras que nos faz retomar o sabor dos cânones de Elvira.

A expressão "sobrevivências pagãs" respaldaria a idéia de um cristianismo hegemônico que aflora no relato de João de Bíclaro (BICL. Chron. XX,5; XXIV,1) e, posteriormente, de Isidoro de Sevilha, para quem "Recaredo se converteu, com efeito, à fé católica e levou ao culto da verdadeira fé toda a nação gótica, apagando assim a mancha de um erro enraizado" (ISID. HG 52). Também a considerar que o paganismo se restringiria a resquícios de crenças, práticas e ritos, formas vazias que a ação pastoral se encarregaria de tentar apagar, quando não fossem obliterados ou desnaturados e, consequentemente, incorporados pelo cristianismo. Apesar de se reconhecer que as práticas pagãs não estavam restritas apenas a algumas áreas da Península, inclusive durante o século VII, ponderou-se que a unidade religiosa da Monarquia católica de Toledo não teria tido problemas maiores senão com a minoria judaica (ORLANDIS, 1991, v.1, p. 433-434; 446-448). Atentou-se para o maior arraigamento das práticas pagãs nas áreas periféricas, montanhosas 
e escassamente romanizadas, tais como a Galiza e a região basco-cantábrica. Quase sempre, ele se ambientaria nos distritos rurais, em meio aos camponeses e às mais ínfimas categorias sociais ali existentes, segmentos que representariam "seguramente, os níveis culturais mais baixos da população", atribuindo-se sua persistência nessas áreas ao conservadorismo da mentalidade camponesa, à falta de pregação ou ainda a motivos de índole social, como expressões de oposição ${ }^{27}$. Em suma, as práticas pagãs persistiriam "sobretudo, entre os humildes" (KING, 1981, p.172).

Todavia, se, ideologicamente, o cristianismo, que passara a justificar a Monarquia visigoda, opunha-se àquelas práticas consideradas pagãs, no campo religioso elas se confundiam com o cristianismo, fazendo parte de um mesmo conjunto de concepções e sentimentos, resultando numa profunda identificação inconsciente (FRANCO Jr., 1996, p.37). Uma nova fé deve abrir passagem e construir seus espaços sobre crenças, usos e costumes religiosos que não se difundiram graças a uma autoridade individual, mas que formava parte do passado (GIORDANO, 1983, p. 13-14), elaborando articulações dentro de uma nova realidade. Assim, concordamos com J-C.Schmitt quando afirma ser falsa a idéia das "sobrevivências" pagãs: "toda crença ou rito, mais do que uma combinação de tradições, é uma experiência que tem sentido somente na sua coesão presente" (SCHMITT, 1976, p. 944-946). Ou seja: os ritos e práticas pagãs não se restingiam a meras "sobrevivências"; tampouco seriam simples gestos ou automatismos conservados de forma vazia, mas implicavam uma sensibilidade ativa, uma realidade viva e vivenciada de forma coerente pela religiosidade da época em que foram notadas e apontadas pelos autores cristãos.

Essa tendência em efetuar a vinculação das práticas pagãs dos servi ou, mais amplamente, dos rustici, talvez tenha origem na aproximação das aristocracias laica e clerical e nas condições em que se organiza e evolui a sociedade hispano-goda. Sob a designação de ingenui se aloca a população mais numerosa da Espanha visigoda, de condição jurídica livre e com matizes internos relacionados à situação econômica, profissão, local de habitação (cidade ou campo), etc. Mas em razão da intensa ruralização social, a redução da pequena e média propriedade livre, a paulatina concentração fundiária e o crescimento contínuo das relações de dependência, a sociedade hispano-goda encaminha-se para um extremo distanciamento entre poderosos e humildes, declinando aquilo a que poderiamos ter denomidado de "grupo intermediário". Havia inclusive, uma estreita ligação entre honestas e riqueza, que desempenhou papel fundamental na sociedade visigoda da Hispânoa, na qual o contrário de nobilis era pauper, e na qual a força atribuída ao testemunho de um livre em um tribunal 
dependia de seus meios econômicos. As poucas menções que os textos fazem aos camponeses e coloni mostram a tendência a homogeneização jurídica, sob o status de "escravo" de todos os camponeses dependentes que trabalhavam nas grandes propriedades. Assim, apesar das diferenças entre servos, servos eclesiásticos, servos fiscais, libertos, livres, colonos, camponeses, etc., a tendência predominante era no sentido da bipolarização social e ao desaparecimento do camponês livre, como no restante da Europa (VALDEAVELLANO, 1982, p. 181; GARCÍA DE CORTÁZAR, 1983, p.20-24; KING, P.D. Op.Cit., p.210; GARCÍA MORENO, L.A. HETL,v.2, p.386. ${ }^{28}$

Outro elemento que também auxilia na aproximação práticas pagãs/ servi-rustici é a tese de que as manifestações religiosas da massa estão estreitamente vinculadas ao seu inato desejo de libertação e de promoção social. De fato, é inegável que muito das permanências pagãs, das heresias e dos cismas dos primeiros séculos cristãos tivessem fortes e claros vínculos com as condições materiais e sociais do Baixo Império, para as quais as primeiras grandes migrações do século V não representaram interrupção, mas continuidade. A instalação definitiva dos visigodos na península, a organização e progressiva cristianização do seu reino, não implicaram uma ruptura do processo que a região vinha sofrendo: prossegue a regressão econômico-demográfica, a ruralização, o declínio urbano e a concentração fundiária, que fora iniciada pela Igreja e pela aristocracia hispano-romana, vê-se sequenciada. Mas se é lícito concordar que muito das permanências pagãs estivessem ligadas âs condições econômico-sociais, nos é difícil concordar que elas significariam somente elementos de resistência, "tábuas de salvação" de uma maioria populacional oprimida, uma vez que, às vésperas da invasão muçulmana, "existiam ainda práticas pagãs e não apenas no campo ou apenas entre os escravos" (THOMPSON, p. 352).

Apenas a título de exemplo, ainda no século VI, poderíamos retomar o próprio Martinho de Braga e seus Capitula Martini, uma coleção de cânones tomados dos concílios orientais, incluídos como apendice do 2Braga (572), portanto às vésperas da conversão dos visigodos ao catolicismo. A título de exemplo, verificamos ali chamadas como: "Que não seja lícito aos bispos ou aos clérigos fazer encantamentos ou ligaduras"; "que não está permitido celebrar missa sobre a tumba dos mortos" 29 . A estes dois cânones, que fazem menção explícita às práticas pouco ortodoxas do ordo clericorum, somam-se outros a respeito dos cristão ${ }^{30}$ em que se proíbe levar alimentos às tumbas, de se atentar às superstições, guardar as tradições dos gentios ou guiar-se pelo curso da lua ou das estrelas, ou de as mulheres se utilizarem de fórmulas supersticiosas em seus tecidos de lã. De forma mais ampla, proibe a 
comemoração das calendas, o recolhimento de ervas medicinais com alguma superstição, a união com animais (2Braga, Capitula Martini,49,71,72,75,78,81 ep.). Nota-se que os Capitula Martini relaciona uma série de práticas pagãs encontradas também no De corretione rusticorum. Atesta assim a ausência de regionalidade de tais práticas - já que os cânones do Capitula Martini são extraídos de concílios orientais - e, paralelamente, a inserção do ordo clericorum em meio a elas. Torna-se difícil, desta forma, identificar as persistências pagãs "apenas" como vinculadas aos servi-rustici e/ou reflexos de uma situação de protesto contra a ordem estabelecida ou contra a situação econômico-social, já que a ordo clericorum representa essa "ordem" e os termos sacerdotibus vel clericis do cânone 59 não deixa dúvidas sobre a origem social e postos que ocupam os indivíduos aos quais se dirige. E se Martinho de Braga teve o cuidado de extraí-los dos concílios orientais, é porque cabiam no contexto peninsular.

A partir da conversão de Recaredo ao catolicismo, em fins do século VI, o catolicismo se transformou no fundamento ideológico da sociedade do reino visigodo. identificada com o poder da Monarquia e com os privilégios dos potentiores, a Igreja acirra sua luta contra a heresia, o judaísmo e as práticas pagãs no reino. Presumiu-se a partir do abandono do arianismo, na expressão de P.D.King, a formação de uma "societas fidelium Christi" (KING, 1981, p.155 ep), com Recaredo sendo chamado de "sanctissimus". A composição do reino é entendida como o conjunto de nações que não é mais o Império, mas a Igreja, unido pela fé: “unus Dei populus, unumque regnum" 31 . A integração rex-regnum, operar-se-ia através do juramento de fidelidade, cujo rompimento implicaria uma desfeita ao próprio Deus, de quem o rei é o legítimo representante. Daí a insistência nos concílios em anatematizar o crime de infidelitas, identificado como sacrilégio.

É, pois, perceptível quão perigosas seriam, ideologicamente, a permanência das heresias, do paganismo e do judaísmo nesse contexto. Para além do arianismo, os inícios do reino católico de Toledo teria ainda que se confrontar com o priscilianismo tardio, particularmente na Galiza. Os judeus formavam uma pequena, mas significativa comunidade. Eram marginais por excelência da "societas fidelium Christi", logo sendo postos em equivalência aos libertos e servos não fiscais, com uma condição jurídico-institucional semelhante à dos servos privados, sem qualificações para ter acesso à administração pública ou cargos do Oficio Palatino (BARBERO; VIGIL, 1978, p.185). Quanto às heresias, parece que não foram um problema para a Igreja visigoda católica, que se manteve dentro da mais pura ortodoxia GONZÁLEZ, 1979, p. 683-689. Portanto, no que concernia à religião, para 
além da mencionada comunidade judáica, seria contra as práticas pagãs, “arraigados em determinadas regiões periféricas e montanhosas, escassamente romanizadas" (ORLANDIS, 1991, v.1, p. 433-434; 446-448) que clamariam os concílios de Toledo até o final do século VII.

Por isso, é difícil concordarmos com a afirmação isidoriana de que, sobre a conversão oficial de Recaredo, em 589 diz que: "Desde os inícios mesmo de seu reinado, com efeito, Recaredo se converteu à fé católica, e levou o culto da verdadeira fé à toda nação gótica, apagando assim a mancha de um erro enraizado" (ISID. HG 52). Como já o apontamos, o sentimento religioso se situa na estrutura mental, da qual ele faz parte; a mentalidade dos homens se transforma muito mais lentamente que a economia e a sociedade: a história das mentalidades é a "história da lentidão na história" (LE GOFF, 1976, p. 72). Converteu-se, de fato, todo o reino hispano-godo com Recaredo? É necessário lembrar que as conversões em massa não implicam uma viragem radical das tradições, práticas ou convicções religiosas de uma população. O conceito cristão de conversão implica uma atitude particular diante da existência. No batismo exige-se de maneira formal a renúncia ao Diabo, seus anjos, cultos, ídolos, furtos, fraudes, impurezas e gulas, e também a confissão de crença no Pai, Filho, Espirito Santo, esperança no fim do século, na ressureição da carne e na vida eterna. É uma completa mudança na vida espiritual e comportamento moral. Em outros termos, uma metánoia total e autêntica, somente produzida no âmbito individual e por iniciativa de personalidades particulares (GIORDANO, 1983, p.17-18; MART.BRAC. De corretione rusticorum, 8). As conversões em massa, pois, apresentavam mais algo de "espetacular", de "exemplum", com a criação de inúmeros cristãos de nome, mas poucos por convicção. Some-se a isso os vários outros motivos, alheios às esferas religiosas que promoviam essas conversões. Nos restingiremos aqui, a título de exemplificação à questão da idolatria $^{32}$, significativamente tratada de forma explícita e, dado importante, ao menos em duas delas, por expressa vontade régia.

No concílio de 589, ficava reconhecido que "por se encontrar muito arraigado em quase toda a Espanha e a Gália o sacrilégio da idolatria, com o consentimento do gloriosíssimo rei, o santo concílio ordenou o seguinte: Que na sua diocese, cada bispo, unindo-se ao juíz do distrito, investiguem minuciosamente a respeito do dito sacrilégio, e não demorem para exterminar aquilo que for encontrado e, quanto aqueles que frequentam tais erros, salvo sempre sua vida, castiguem-nos com as penas que puderem e, saibam ambos (juíz e bispo) que se preocuparem em agir assim, incorrerão na pena de excomunhão e, se alguns senhores não se preocuparem com a extirpação 
desse pecado em suas propriedades, ou não desejando coibir seus servos, também eles serão privados pelo bispo da comunhão" (3Toledo,16 - 589).

Já próximo ao término do reino de Toledo, em 681, sob o título "Dos adoradores dosídolos", ponderava-se:

São preceitos do Senhor que disse: 'Não farás para tí obra de escultura, nem figura alguma do que há acima no céu, nem do que há abaixo na terra, nem das coisas que estão nas águas debaixo da terra; não as adorarás nem lhes dará culto. Além disso, aquele que sacrifica aos deuses e não somente ao Senhor, será morto'. E noutra parte: 'O homem ou a mulher que faz o mal na presença do Senhor teu Deus, e viola o pacto do Senhor, indo servir a deuses estranhos e adorá-los, e ao sol e à lua e à toda a milícia do céu, o que eu não determinei, se te avisarem disso, ao escutar farás com toda diligência uma investigação, e se encontrares que é verdade e que em Israel se tem praticado tal abominação, levarás o varão e a mulher que executaram um crime tão malvado às portas da cidade e serão apedrejados'. Recordanto esses preceitos do Senhor, não para castigar os delinqüentes, mas para amedrontá-los, não imporemos por esse nosso decreto a pena de morte, mas avisamos aos adoradores de ídolos, aos que veneram as pedras, aos que ascendem velas e adoram as fontes e as árvores, que reconheçam como, expontaneamente, condenam-se à morte aqueles que fazem sacrifícios ao diabo. Pois o diabo leva o nome de morte, conforme o que está escrito a seu respeito: 'E morte era seu nome'. $\mathrm{E}$, portanto, todo sacrilégio de idolatria, e qualquer coisa contrária à santa fé, que os homens nécios, escravisados pelo culto do diabo praticam, por intervenção do bispo ou do juíz, onde quer que tenha sido descoberto algum desses sacrilégios, sejam arrancados pela raíz e, uma vez arrancados, sejam aniquilados; e castiguem com açoites a todos aqueles que participam de um horror dessa natureza, prendendo-os com correntes, entreguem-nos aos seus senhores, sempre que os seus donos prometam, mediante juramento, que eles os vigiarão tão cuidadosamente que não lhes seja possível, dalí por diante, que cometam tais crimes. Mas se seus donos não quiserem receber sob a sua palavra aos mencionados réus, que sejam então apresentados diante do rei por aqueles que lhe impuseram o castigo, para que a dignidade régia tenha a livre faculdade de doá-los; e seus donos, tendo recebido a denúncia dos erros de tais servos, tenham demorado em castigá-los, sofrerão pena de excomunhão, e saibam que perderão todos seus direitos sobre aquele servo que não quiseram castigar. $\mathrm{E}$, se por acaso, forem pessoas livres (ingenuorum personae) que estiverem implicadas nestes erros, serão castigadas com a pena de excomunhão perpétua, e enviados ao desterro (12Toledo,11 - 681). 
No penúltimo concílio do reino, em 681, voltamos a encontrar o título "Dos adoradores de ídolos" para o mais extenso dos três cânones que mencionamos.

É coisa evidente que o inimigo do gênero humano, segundo disse o Apóstolo, corre pelo mundo rugindo e buscando a quem devorar, posto que, valendo-se de diversas astúcias e tergiversações, enganando a muitos nécios, não cessa de enredá-los em seus laços; e ainda que o Senhor tivesse mandado não farás para tí escultura alguma, nem nenhuma imagem do que há acima no céu nem do que há abaixo na terra, etc.(sic), e, noutra parte, 'Não os fareis, ídolos ou esculturas, nem lentantareis santuários, nem colocareis pedras insignes em vossa terra para adorá-la', e mais adiante: 'Adorarás ao Senhor teu Deus e somente servirás a Ele', eles, enganados por diversas persuações, converteram-se em adoradores de ídolos, veneradores das pedras, acendedores de velas, e rendem culto aos lugares sagrados das fontes e das árvores, e se tornam augures ou encantadores, e muitas outras coisas que seria longo narrar. E porque ele não é seu criador, nem seu senhor, nem seu redentor, convém extremamente aos dirigentes das igrejas de Deus, cuidar para que aqueles a quem o mesmo inimigo havia dominado mediante malignas persuações fazendo-lhes cometer diversos sacrilégios, tirando-os das garras desse inimigo, possam restituí-los ao seu criador.

E porque a respeito da extirpação desses sacrilégios, foram promulgados em diversos concílios muitos editos dos santos Padres, temos recorrido numa busca cuidadosa e temos examinado suas disposições com discrição e seriedade, e porque parecem plenamente razoáveis, decretamos com o consentimento e ordem entusiasmada do religiosíssimo senhor nosso rei Egica, que todos os bispos e presbíteros e todos aqueles que estão à frente das causas judiciais, vigiem com o maior esmero; onde quer que encontrem alguns adorando ou praticando os referidos sacrilégios, ou qualquer outra das coisas que se proíbe pela lei divina, ou vedadas pelas determinações dos santos Padres, sejam pessoas de qualquer gênero ou condição (cuiuscumque sint generis aut conditionis), imediatamente, atendo-se ao conteúdo das referidas disposições, não demorem em corrigí-los e extirpá-los, e também apresentarão quantos dons foram oferecidos no mesmo lugar do sacrilégio, às igrejas vizinhas, na presença daqueles que tinham desejado dedicá-los com esse voto sacrílego.

E se o bispo, presbítero ou juíz, a cuja jurisdição pertencer aquele local, tendo notícia de um crime público ou privado de qualquer caráter sacrílego se descuidar de corrigí-lo prontamente, privado da dignidade de seu posto, será submetido à penitência durante o espaço de um ano, voltando ao seu posto depois de cumprida: de tal modo que durante o tempo em que aquele esteve suspenso de seu ofício e posto, eleja o príncipe, 
para esse caso, alguém cheio de temor a Deus e (...) abrasado no zelo espiritual, em união com os juízes como dissemos, extirpe por todos os meios qualquer sacrilégio que encontrar e afaste a ira do Senhor de todo o povo. E se alguém, na defesa de tais sujeitos, fizer oposição aos bispos ou aos juízes, para que não possam corrigir como é seu dever, ou extirpar como é conveniente os sacrílegos, e não se prestar melhor a estar com estes, investigadores, vingadores e extirpadores de um crime tão grave, seja anatematizado na presença da indivisível Trindade, e além disso, se for uma pessoa nobre (si nobilis persona fuerit), pague três libras de ouro ao sacratíssimo fisco, e se pessoa inferior (si inferior), seja açoitado com cem golpes e vergonhosamente tonsurado e, além disso, lhe será tomada em favor do fisco a metade de todos os seus bens" (16Toledo, 2 - 693).

Algumas análises historiográficas sobre estes três cânones apontam, inicialmente, resíduos idolátricos, reconhecendo para a época do 12Toledo o fato deles não estarem circunscritos a uma região - mas apontam como mais intensos no Norte, entre os bascos. Para o final da época visigoda, fala-se em "sobrevivências" pagãs em comarcas separadas das diversas províncias, "em ambientes camponeses e com preferência entre os servos rústicos que representavam, seguramente, os níveis culturais mais baixos da população”. Apontam a menção de 681 aos "ingenuorum personae" e reafirmam que a maioria dos casos se davam "entre os servos rurais". Destacam no XVI Concílio de Toledo as medidas para a repressão da idolatria, a questão da entrega dos "dons" para as igrejas próximas. Questiona-se se essa resistência dos pagãos em abandonarem tais práticas se vincularia à falta de pregação,ou ao conservadorismo da mentalidade camponesa, ou ainda a motivos de índole social, como expressão de oposição. Mais uma vez se reafirma: "pertenciam quase que exclusivamente ao mundo rural e às mais ínfimas categorias sociais existentes no campo" ${ }^{33}$ Parece unânime nesta rápida amostragem: as práticas pagãs sobreviviam "sobretudo, entre os humildes" (KING, 1981, p.172).

Os mesmos elementos encontrados no De corretione rusticorum, pouco mais de um século antes dos últimos concílios de Toledo: veneração de pedras, acender velas, adorar fontes e árvores, agoureiros e encantadores... Sem dúvida, o paganismo é uma das formas mais significativas de expressão da chamada "religiosidade popular". Mas há que se considerar que "o fato religioso é uma realidade una que torna artificial e arbitrária uma distinção forte entre religiosidade erudita e religiosidade popular". Uma nova fé deve abrir passagem e construir seus espaços sobre crenças, usos e costumes religiosos que não se difundiram graças a uma autoridade individual, mas que formava parte do passado, elaborando articulações dentro de uma nova 
realidade, sendo assim falsa a ideia das "sobrevivências" pagãs: como já dissemos, "toda crença ou rito, mais do que uma combinação de tradições, é uma experiência que tem sentido somente na sua coesão presente" (GIORDANO, 1983, p. 13-14; SCHMITT, 1976, p. 944-946).

Procedente de mesclas, fusões, inserção em um processo em andamento, a "aristocracia laica medieval não difere muito dos rustici”. Há uma indiferenciação crescente, onde se notam poucas exceções, de todas as camadas sociais laicas em face do clero, que monopoliza todas as formas evoluidas, e, nomeadamente escritas, de cultura. Os "rustici da Alta Idade Média não podem ser qualificados de pagãos unicamente porque tenderam a conservar velhos ritos, dos quais amiúde, eram os primeiros a ter perdido a mais autêntica chave interpretativa”. Na época da confissão de fé de Recaredo, no 3Toledo de 589, já nos encontrávamos em uma sociedade em que o maior peso vinha dos meios rurais. A grande questão que se colocava, não era a da sua cristianização, mas sim a da sua efetiva conversão. Tal era o preço a ser pago pela "espetacular" mudança de religião: a presistência de diversas formas e de velhos cultos que mesclavam tradições célticas, romanas, mediterrânicas. A massa, se não se encontrava totalmente ausente, estava bem distante de tais acontecimentos. O ordo laicorum é, pois, predominantemente rural e, diante do retrocesso do paganismo oficial, encontra-se vulnerável às culturas primitivas renascentes. A proposta de imediata vinculação práticas pagãs/servi-rustici deixa assim de ser tão plausível. A civilização visigoda católica da Espanha é, sem dúvida, a "civilização de uma minoria" (CARDINI, 1982, p. 27-28; LE GOFF, 1979, p. 208-209; GARCÍA DE CORTÁZAR, p. 43; KING, 1981, p.102).

Poderíamos excetuar o ordo clericorum? A resposta nos parece negativa. Os cânones do 4Toledo (633) estão plenos de reclamações da qualidade moral e cultural dos bispos. Também em relação às formas de obtenção dos cargos eclesiásticos. Estes representavam uma das formas de ascensão social dentro do reino visigodo e, como não havia uma ampla proliferação de vocações religiosas, também servos - com as devidas ressalvas apontadas nos cânones conciliares - eram recrutados para ocuparem cargos menores.

Culturalmente, é possível crer que houvesse - apesar das diferenças regionais - uma certa homogeneidade no ordo clericorum (LE GOFF, 1979, p.210). No entanto, ela não se espelha nos quadros sociais. Além dos cânones já citados dos Capitula Martini, que são anteriores à conversão de Recaredo, outras reprimendas conciliares posteriores nos mostram, por exemplo, sobre "clérigos que consultam aos magos ou adivinhos" ou de clérigos que "no sacrifício do Senhor oferecem leite no lugar do vinho ou também um cacho de uvas, e crêem que se deve dar ao povo a eucaristia empapada em vinho" (4Toledo; 
3Braga, 11Toledo, ep.). Dificilmente a distinção entre ordo clericorum e o ordo laicorum seria encontrada nos indivíduos que compunham seus quadros. Não bastava ser cristão para fazer parte da gens sancta: os camponeses, apesar de suas superstições "não duvidavam de ser cristãos" (LE GOFF, 1979, p.210).

Há práticas pagãs na aristocracia laica e clerical, no campo e também nas cidades. O que se repara nos cânones sobre idolatria citados, é que com o passar dos anos, eles crescem, não apenas em extensão, mas especialmente em severidade. É um fenômeno que corre paralelo à legislação laica durante o século VII, que chega a impor quinhentas chicotadas - para os adivinhos -, tortura e venda fora do país para os envolvidos em práticas pagãs (THOMPSON, 1971, p. 350-352). As leis civis visigodas, ativeram-se até a sua ultima recompilação, provavelmente realizada na época de Recesvinto (653672), somente na magia e adivinhação. Os cânones conciliares nos permitem um leque maior das persistências. Se as práticas se achavam disseminadas, o mesmo não podemos afirmar quanto aos cultos pagãos que, para fins do século VII, só se conhece concretamente um caso, próximo a Astorga e que incluía até um santuário (THOMPSON, 1971, p. 350-352).

A que se deve essa crescente severidade contra as práticas pagãs ainda é um problema que merece uma melhor análise. Estaria relacionado ao clima de tensão política dos últimos anos do reino? Adivinhos e encantadores poderiam tentar saber sobre a saúde do monarca ou mesmo provocar-lhe malefícios. Tal é uma das razões da preferência da legislação laica pelos magos e adivinhos. Mas isso nos parece insuficiente para elucidar o crescente rigor legal. Poder-se-ia também tentar relacionar às fomes e pestes, que assolaram a península nos últimos anos do reino visigodo, ou ainda ao crescente estado de miséria dos humiliores, hipóteses que necessitam ser mais aprofundadas. A menção feita aos “ingenuorum personae" pelo 12Toledo não deve, portanto, conduzir-nos a rápidas conclusões, a entendimentos precipitados. Nos três cânones sobre idolatria que mencionamos aqui, os servi são apontados como principais culpados desse sacrilégio. Mas em meio a uma sociedade predominantemente rural, com uma aristocracia laica que não dista muito dos rustici, e um ordo clericorum nem sempre muito ortodoxa e uma forte tendência à bipolarização social entre poderosos e humildes, não seria lícito considerarmos, a título de hipótese, estes ingenui mais como figuras jurídicas que efetivamente sociais? A utilização do termo "inferior" (16Toledo,2) não seria já um indício dessa situação? Se é certo que não devemos generalizar excessivamente essa bipolarização social, também não o é tentar achar diversos matizes sociais, já que eles perdem sua importância no conjunto social e na sua tendência de alargamento do fosso social. 
Como considera Hilário Franco Jr, indissociável da cultura folclórica, as práticas pagãs se inserem na chamada "religiosidade popular". Essa última se exprime de formas diferentes, com relações dialéticas, de influências recíprocas, significando simultaneamente "criado e praticado pelo povo, mas também recebido e incorporado e/ou adaptado por ele". Uma nova religião somente atrai fiéis se se apoia nos instintos e características religiosas já presentes entre os homens a que se dirige. Da destruição de ídolos empreendida pela evangelização urbana, passou-se inadvertidamente para o "exemplo" dos mosteiros, dos "homens santos". Mais extremista e individual, inicialmente fruto de uma sensibilidade ascética, o monasticismo, inicialmente visto com desconfianças pela hierarquia eclesiástica teve, posteriormente e com diversas adaptações e "regras", um enorme sucesso na Hispânoa visigoda, especialmente na segunda metade do século VII, época de uma mais acentuada ruralização econômico-social. Refletiriam suas posturas mais extremistas, uma resposta mais incisiva para os humiliores, descontentes com a ordem estabelecida? Seu lado ascético reflitiria melhor a sensibilidade religiosa dos mais simples? $\mathrm{O}$ antigo receio da hierarquia eclesiástica, paliatizado momentaneamente pelos mosteiros urbanos ou semi-urbanos, converteu-se em fins do reino de Toledo, em franca hostilidade, (GARCÍA MORENO, 1982, v. 2, p. 398), diante de suas formas mais fluidas, muitas vezes distorcidas e, especialmente independente diante do episcopado urbano. Coincidência com a crescente severidade dos cânones citados?

Mas o que nos fica claro, por fim, é que as práticas pagãs não se resumiam a vestígios ou simples resquícios; que elas não estavam arraigadas somente em algumas áreas periféricas ou tinha se tornado monopólio dos humildes, dos indivíduos pertencentes aos níveis culturais mais ínfimos da população. Ela estava presente, como vimos, no próprio seio do ordo clericorum, que aliás era local importante das influências recíprocas entre os dois níveis religiosos. Tampouco elas se vinculam "apenas" a resistências ou protestos à ordem econômica e social instalada. Se os cânones mencionam encantos e malefícios mágicos contra o monarca, é certo que não seriam o camponês ou servo, de distantes regiões rurais, os mais interessados em atentar contra o rei. Obras como o De corretione rusticorum não iam, na realidade, dirigidos apenas ao povo, "que dificilmente estaria capacitado a lê-los” (GIORDANO, 1983, p. 256), mas também aos clérigos como referências para sua pregação a seus paroquianos.

Na questão da omissão e/ou demora na ação contra a idolatria, nota-se que, nos dois primeiros cânones, só se fala em omissão; o segundo já apresenta castigo; o terceiro fala em obstrução e apresenta penas mais severas. 
Estaria esse procedimento de bispos, juízes e nobilis relacionado ao temor de uma reação mais violenta por parte dos rustici? Esse provável temor não justificaria as omissões e/ou obstruções mencionadas? O temor hipotético de uma revolta significativa não poderia estar ligado à tensão, fome e peste que, de forma endêmica grassaram o reino e, de forma acentuada em seus últimos tempos? Tais hipóteses não reforçariam a tese dos vínculos econômicos e sociais das práticas pagãs? Estas omissões e/ou obstruções não poderiam também estar ligadas à sensibilidade religiosa dos domini? Poderia a maior severidade das leis indicar um sintoma de seu alastramento, ou mesmo de que tais práticas encontravam-se mais enraizadas do que até agora se supôs? Além de outras mostras, para além dos cânones conciliares, poderiam ser acrescentadas à questão da idolatria à qual nos limitamos aqui. Assim, são diversos os problemas e dúvidas que permanecem sobre a efetiva conversão ao catolicismo da Hispânia visigoda.

\section{THE VISIGOTHIC KINGDOM: CATHOLICISM AND PAGAN PERMANENCIES}

AвSTRACT: What became accustomed to call "paganism" is undoubtedly one of the most significant forms of what is designated as "popular religiosity". This expression, which seems useful when a generalization is required, shows all its weakness when a more precise and objective observation of a particular religion is attempted. Would the official visigothic kingdom's "conversion" to Catholicism, with Recardo (586-601) at the Council of Toledo of 589 have effectively matched to the "conversion" of this kingdom's population? Firstly, it is necessary to consider, in beyond the exalting intentions of the sources of that moment, that mass conversions do not imply a radical change in the convictions and religious practices of an entire people. Secondly, that "conversion" and "Christianization" are not synonymous. "Religiosity", which includes the "conversion", implies a fundamental religious attitude, which can simply be interior and personal. On the other hand, "religion", in which "Christianization" is included, would correspond to a public aspect, institutionalized, which elaborates a set of techniques aiming, as in the case of "religiosity", the guarantee of the supernatural Thus, elevated to the position of "official religion," Catholic Christianity would live with a series of rites, rituals, devotions, from the previous "religiosity" that, through its ecclesiastical perspective, would be reprehensible, considered marginal and something that would lead to error. However, on the eve of the Muslim invasion in 711, not only among the laity but even in ecclesiastical segments, the manifestations of the "paganism" still were aim of coactive condemnation in the Catholic kingdom of Toledo's councils.

KeY wORDS: Christianization; conversion; paganism. 
NOTAS

1 JUAN DE BÍCLARO Chronicon. Ed. Crítica de J. Campos Juan de Bíclaro, obispo de Gerona. Su vida y su obra. Madrid: CSIC, 1960. A partir de agora citado como BICL. Chron. aprox.587,5.

2 ISIDORO DE SEVILLA História Gothorum, Vandalorum et Suevorum. Ed. bilíngue (latim-espanhol) de C. Rodríguez Alonso. León: Centro de Estudios e Investigaciones "San Isidoro", 1975. A partir de agora citado como ISID. HG 49.

3 Leia-se "Terceiro Concílio de Toledo do ano de 589".

4 VITAS SANCTORUM PATRUM EMERITENSIUM. Ed. bilíngue (latim-inglês) de J. N. Garvin. Washington DC: The Catholic University of América Press, 1946. A partir de agora citado como VSPE 5.4.2. ep.

5 GREGORIO DE TOURS Histoire des Francs. Ed. e trad. de R. Latouche. Paris: Belles Lettres, 1966. A partir de agora citado como GREG.TUR. HF V,38.

6 Não é nosso objetivo ou propósito engrossarmos a polêmica sobre a existência ou não de um "sentimento nacional" ou de um "nacionalismo" espanhol na época visigoda. Esse tema, particularmente na obra isidoriana, é base de um longo e clássico debate historiográfico. Recentemente, esse problema foi exaustivamente tratado por TEILLET,S. Des Goths à la Nation Gothique. Les origines de l'idée de nation en Occident du Ve au VIIe siècle. Paris, Belles Lettres, 1984, especialmente pp.463-536, obra que também elabora um excelente resumo do debate (pp.115) e conclui que "o nascimento da Espanha gótica precede e anuncia aquelas outras nações da Europa moderna, em meio às diferentes provincias romanas invadidas pelas gentes, particularmente na Gália franca onde, em razão do predominância germânica, a assimilação entre Francos e Gauleses realiza-se de forma mais lenta, e a idéia de nação, que se busca em Gregório de Tours, é mais difícil de ser formulada.(...)"(p.643). De nossa parte, preferimos a idéia de uma consciência regional, tal como já havia sido ponderado antes da publicação do trabalho de S.Teillet por J.N.HILLGART "Historiography in Visigothic Spain" In La Storiografia Altomedievale. Settimane di Studio 17. Spoleto: CISAM, 1970, 2v. pp. 261-311; 345-352, v.1; entendendo que o uso da palavra nacionalismo para a época visigoda não seria "uma querela de palavras", mas de alguma coisa mais séria, equivalendo a "despistar a gens", sendo um "anacronismo por excelência"(p.351); também que Isidoro de Sevilha "não escreve uma História da Espanha, mas a História dos Godos"(p.298); não "uma história nacional", mas "uma história real"(p.299).

7 PAULO ORÓSIO Historia Adversum Paganos. Ed. bilíngue (latim-espanhol) de C. Torres Rodrígues. Santiago: Instituto "P. Sarmiento" de Estudios Galegos, 1985. A partir de agora citado como OROS. Historiarum adversum paganos VII.41 
8 HYDÁCIO Chronicon. Ed. bilíngue (latim-francês) de A. Tranoy. 2v. Paris: Cerf, 1974. A partir de agora citado como HYD. Chron. CCLXXXXVII.48.

9 4Toledo, 75 (633). CONCÍLIOS VISIGÓTICOS E HISPANO-ROMANOS. Ed. bilingüe ( latim-espanhol) de J. Vives. Barcelona-Madrid: CSIC, 1963. Nossa citação indica: 4 Concílio de Toledo, cânone 75, ano de 633; seguiremos citando dessa maneira.

10 GARCÍA MORENO, ,v.1, p. 325-326. ISIDORO DE SEVILHA . Etymologiarum VII.14.1, 4ed. de Lindsay (latim). Trad. para o espanhol de J. O. Reta e M. A. A. Casquero, com introdução de M. C. Díaz y Díaz. Madrid, BAC, 1982, 2v. (a partir de agora citado como ISID Etym. VII.14.1, 4 ) associa a origem do termo cristão ao nome de Cristo ou como derivado de seu significado: ungido; cf. tb., p.e. 4Toledo,75; 16Toledo,9 (693) ep. Por seu turno, ISID. Etym. VIII.1.1 deriva católico de Kath'holon, significando "universal", "geral" ou ainda, "de acordo com o total". O arianismo encontra-se catalogado entre as "heresias dos cristãos"; cf. ISID. Etym. VIII.5.43, possibilitanto o contraponto entre cristãos arianos e católicos. No período visigótico, os termos "cristão" e "católico" eram utilizados de como equivalentes de forma regular; cf. LYNCH; GALINDO, 1950, p.117.

11 ILDEFONSO DE TOLEDO De itinere desertii quo pergitur post baptismi. Ed. bilíngue (latim-espanhol) de J. Campos e I. Roca In Santos Padres Españoles. Madrid: BAC, 1971, 2v., v.1, p .386-436. A partir de agora citado como ILD. De itinere deserti 83.

12 Alguns autores pensam nas possibilidades de uma origem africana, como DÍAZ Y DÍAZ, 1967, p. 3-14 e BLÁZQUEZ, 1977, p. 467-494, ou italiana, como defende SOTOMAYOR Y MURO, 1979, p.14, 122ss, 132ss.

13 ECHEGARRAY,(1966, p.216), talvez tentando com essa afirmativa ressaltar a exceção cantábrica.

14 Por exemplo 3Toledo, $1 ; 4$ Toledo, 10 que, respectivamente, usam gentilitas e gentilis (paganismo; pagão). ISID. Etym. VIII.10.1-3.

15 ISID. Etym. X.239, define rusticus como o homem que trabalha o campo (rus), a terra, termo tomado do latim significando "do campo, camponês" que, em Castela, também evoluiria no sentido de áspero, rude; cf. COROMINAS; PASCUAL, 1991, v.5, p.100.

16 AGOSTINHO Enarrationum in Psalmos. Ed. bilíngüe (latim-espanhol) de B. Martín Perez. 4v. Madrid: BAC, 1964. A partir de agora citado como AUG. Enarrationum in Psalmos 95.5-6.

17 ISID. Etym. X.244. Nos concílios, 3Toledo, Tomus, (589) p.118, mencionando o arianismo; 4Toledo,63; 6Toledo,3 (638) e 17Toledo,8 (694) para os judeus; 5 Toledo,4 (636) sobre aqueles que conjecturam sobre o futuro dos reis. 
18 Tivemos oportunidade de analisar mais detidamente esses cânones num outro trabalho nosso ANDRADE FILHO, 1996, p. 30-58. Veja-se também McKENNA, 1938;. ANDRADE FILHO, 2012., p.71-99; 101-129.

19 AGOSTINHO De civitate Dei. Ed. bilíngüe (latim-espanhol) de S. Santamarta del Rio e M. F. Lanero. 3ª. Ed. 2v. Madrid: BAC, 1978. A partir de agora citado como AUG. De civitate Dei XXII.8.22.

20 CODEX THEODOSIANUS. Ed. P. Kruegeri e Th. Mommsen. 3v. Hildeshein: Weidmann, 1990.

21 Elvira, p.1; coincidindo nessas áreas com a permanência das organizações sociais e religiões indígenas; cf. VIGIL e CABO, p. 397-398.

22 LEX VISIGOTHORUM XII.2.2, 3.1-2. (LEX VISIGOTHORUM. Ed. K. Zeumer. MGH. Leges I.1. Hanover-Leipzig: Imprensis Bibliopolii Hahniani, 1973- a partir de agora citadas como LV XII.2.2, 3.1-2); 2Sevilha, 12 e 13 (619), menciona a conversão de um bispo da heresia dos acéfalos e reafirma as duas naturezas e a unidade de pessoas em Cristo; 14Toledo (684) e 15Toledo (688) tratam da questão do monotelismo mais por insistência pontifícia que por problemas causados na península por essa heresia, como assinaba BRÁULIO DE SARAGOÇA Epistolae XXI. BRÁUlIO DE SARAGOÇA Epistolae. Ed. bilíngue (latim-espanhol) de L. Riesco Terrero. Serie Filosofia y Letras 31. Sevilla: Publicaciones de la Universidad de Sevilla, 1975. A partir de agora citado como BRAUL. Ep. XXI.

23 SULPÍCIO SEVERO Obras Completas. Trad. de C. Codoñer Merino. Madrid: Tecnos, 1987- a partir de agora citado como SULP.SEV. Chron. II.46.1,5 A acusação de magia na Antigüidade Tardia seria sintoma de concorrência política e instrumento de controle social, possibilitando a eliminação de rivais políticos; cf. BROWN, 1977, p.119-146; acusação fácil de ser feita e difícil de ser refutada e que, nesta época, teria como implicação a pena de morte; cf. McKENNA, p.5456. Sobre a questão priscilianista, veja-se também a recente obra de OLIVARES GUILLEM, 2004.

24 ISIDORO DE SEVILHA Setentiarum I III,34,5. A partir de agora citado como ISID. Sentent. III,34,5.

25 A origem social humilde de muitas das ordens menores já pode ser entrevista em Elvria,80, que cuidava para que não houvesse ordenações de libertos cujos patronos ainda estivessem vivos. 1Toledo, 10 (aprox.400) ampliaria a restrição àqueles que se encontrassem obrigados a outros "por justo contrato ou origem familiar" sem o consentimento explícito dos patronos. Quanto ao episcopado, predominaram os hispano-romanos enquanto durou a monarquia ariana, salvo alguns bispos de origem oriental e outros de origem germânica pré-convertidos ao catolicismo, situação que se modificaria após a conversão do oficial do reino; cf. ORLANDIS, 1991, v.1, p.478; IDEM Iglesia, pp.127-139. 
26 MARTINHO DE BRAGA De correctione rusticorum. Ed. bilíngüe (latimespanhol) de R. Jove Clos. Barcelona: El Albir, 1981. A partir de agora citado como MART.BRAC. De corretione rusticorum 16.

27 McKENNA, 1938, p.121ss, 147ss, permanece como a obra clássica sobre o tema. Cf. tb. ORLANDIS e RAMOS-LISSÓN, 1986, p. .222,420-421; GONZÁLEZ, 1979, p. 663-699; MARTÍNEZ, 1972, p. 489-508; GARCÍA MORENO, 1975, p. 79-81; GARCÍA DE CORTÁZAR, p. 26; THOMPSON, 1952, p. 12-21; BARBERO, 1986, p. 77-114; BARBERO, VIGIL, 1984, p.39. Veja-se também ANDRADE FILHO, 2012.

28 Optaremos aqui os termos servi ou, mais amplamente, rustici, no lugar de "escravo".

29 2Braga, Capitula Martini,54,68 ep. (MARTINHO DE BRAGA Capitula Martini In CONCILIOS VISIGÓTICOS E HISPANO-ROMANOS. Op.Cit. 2Braga)

30 RAMOS-LISSON, 1986, p. 36; Concílio de Elvira, na primeira metade do século IV: distinção entre christianus (que é o catecúmeno) opondo-se a fidelis (que é o batizado).

31 3Toledo, Tomus, p.107; BARBERO, A. e M. VIGIL Feudalismo, Op.Cit., p.175.

32 ISID. Etym. Etym VIII,11,11-14; ídolo é "uma estátia que representa uma figura humana e que foi consagrada". Consequentemente, "idolatria é toda reverência ou servidão a qualquer ídolo", estando associada à ímpia soberba dos homens ou dos demônios" que desejam que lhes sejam rendidas homenagen. Para além dos cultos aos ídolos propriamente ditos, no século IV, a idolatria designaria a adoração da criatura (homem ou diabo), de elementos da naturesa ou de um objeto, abrangendo dessa maneira a maioria das "sobrevivências" pagãs; cf. SCHMITT, 1988, p. 428-429.

33 ORLANDIS, 1986, p. 222, 420-421, 486-487; MCKENNA, 1938, p.116ss; GARCÍA MORENO, 1975, p. 79-81; MARTÍNEZ, 1972, p. 489-508; GONZÁLEZ, 1979, p. 663-668; para citarmos alguns que abordam esses cânones de forma mais específica e dentro uma perspectiva mais cristã.

\section{REFERÊNCIAS}

Agostinho. De civitate Dei. Ed. bilíngüe (latim-espanhol) de S. Santamarta del Rio e M. F. Lanero. 3 ed. 2v. Madrid: BAC, 1978.

Agostinho. Enarrationum in Psalmos. Ed. bilíngüe (latim-espanhol) de B. Martín Perez. 4v. Madrid: BAC, 1964.

Andrade filho, R. de O. Imagem e Reflexo. Religiosidade e Monarquia no Reino Visigodo de Toledo (séculos VI-VIII). São Paulo: Edusp, 2012.

Andrade filho, R. de O. A Conversão do Reino Visigodo ao Catolicismo: circunstâncias e problemáticas. Dimensões, 22, 2009, p.136-146. 
Andrade filho, R de O. O Reino Visigodo Católico (Séculos VI-VIII): Cristianização ou Conversão?. Politea. História e Sociedade, vol. 5, n.1, 2005.

Andrade filho, R. de O. Cultura e 'Religião’ no Reino de Toledo (séculos VIVIII). In: Andrade Filho, R. de O. (org.) Relações de Poder, Educação e Cultura na Antiguidade e Idade Média. Santana de Parnaíba: Solis, 2005.

Andrade Filho, R. de O. Ensaio sobre a religiosidade popular na Hispânia do século IV: o Concílio de Elvira. Revista Américas. Historia e cultura Ibero-Americana, 2, 1996, p. 30-58.

ArCE, J. Conflicto entre paganismo y cristianismo en Hispania durante el siglo IV. In: Arce, J. España entre el mundo antiguo y el mundo medieval. Madrid: Taurus, 1988.

BArbero, A. El priscilianismo: herejía o movimiento social? In: Conflictos y estructuras sociales en la Hispania Antigua. Madrid: Akal, 1986.

Barbero, A.; Vigil, M. La Formación del Feudalismo en la Península Ibérica. Barcelona: Crítica, 1978.

Barbero, A.; Vigil, M. Sobre los orígenes sociales de la Reconquista. Barcelona: Ariel, 1974.

BlázQuez, J. M. Imagen y Mito. Estudios sobre religiones mediterráneas e ibéricas. Madrid: Cristandad, 1977.

Blázquez, J. M. Diccionario de las Religiones Prerromanas de Hispania. Madrid: Istmo, 1975.

Bráulio De Saragoça. Epistolae. Ed. bilíngue (latim-espanhol) de L. Riesco Terrero. Serie Filosofia y Letras 31. Sevilla: Publicaciones de la Universidad de Sevilla, 1975.

Brown, P. Religion and society in the age of Saint Augustine. London: Farber, 1977.

Cardini, F. Magia, Brujería y Superstición en el Occidente Medieval. Barcelona: Península, 1982.

Chadwick, H. Prisciliano de Ávila. Ocultismo y poderes carismáticos en la Iglesia primitiva. Madrid: Espasa-Calpe, 1978.

Codex Theodosianus. Ed. P. Kruegeri e Th. Mommsen. 3v. Hildeshein: Weidmann, 1990.

Concilia Galliae (314-506). Ed. C. Munier. Corpus Christianorum - Series Latina CXLVIII. Turnholti: Brepols, 1963.

Concílios Visigóticos e Hispano-Romanos. Ed. bilingüe ( latim-espanhol) de J. Vives. Barcelona-Madrid: CSIC, 1963.

Corominas, J.; Pascual, J. A. Diccionario crítico etimológico castellano e hispánico. 6v. 2 reimpr. Madrid: Gredos, 1991. 
Cortázar, J. A. Historia de España Alfaguara II. La Epoca Medieval. Madrid: Alianza, 1983.

Díaz Y Díaz, M. C. Prólogo. In: Jover Zamora, J. M. (dir.) Historia de España. Menéndez Pidal. España Visigoda. T.III, 2v. Madrid: Espasa-Calpe, 1991.

Díaz Y DíAz, M. C. En torno a los orígenes del cristianismo hispánico. Las raícez de España 16. Madrid: Instituto Español de Antropología Aplicada, 1967.

Echegarray, J. G. Los cántabros. Madrid: Guadarrama, 1966.

Escribano, M. V. Herejía y poder en el siglo IV. In: Candau, J. M. et al. (ed.) La conversión de Roma. Cristianismo y paganismo. Madrid: Ediciones Clásicas, 1990.

Fontaine, J. Conversion et culture chez les wisigoths d'Espagne. La consersione al Christianismo dell'alto medioevo. Settimane di Studio 14. Spoleto, Centro Italiano di Studi sull;alto Medioevo, 1967.

Franco JR., H. Peregrinos, monges e guerreiros. Feudo-Clericalismo e Religiosidade em Castela Medieval. São Paulo: Hucitec, 1990.

Franco JR., H. Meu, Teu, Nosso. Reflexões sobre o conceito de cultura intermediária. In: Franco JR., H. A Eva Barbada. São Paulo: Edusp, 1996.

Franco Jr., H. Cristianismo medieval e mitologia. In; Franco Jr., H. A Eva Barbada. São Paulo: Edusp, 1996.

García De La Fuente, O. El latín Bíblico y el Español Medieval hasta el 1300 I. 2ed. Logroño: Gobierno de la Rioja - Instituto de Estudios Riojanos, 1991.

García Moreno, L. A. Élites e Iglesia hispanas en la transición del Imperio Romano al Reino Visigodo. In: CANDAU, J. M. et al. (ed.) La conversión de Roma. Cristianismo y paganismo. Madrid: Ediciones Clásicas, 1990.

García Moreno, L. A. El fin del reino visigodo de Toledo. Madrid: Universidad Autonoma, 1975.

García Moreno, L.A. Las invasiones y la época visigoda. Reinos y condados cristianos. In: TuÑon De Lara,M. (dir) Historia de España I. Introducción, primeras culturas y Hispania romana. 11v. 3ed. Barcelona: Labor, 1982.

Giordano, O. Religiosidad popular en la Alta Edad Media. Madrid: Gredos, 1983.

GonzÁlez, T. La Iglesia desde la conversión de Recaredo hasta la invasión árabe. In: GarcöA-VillosladA, R. (dir) Historia de la Iglesia en España I. La Iglesia en la España romana y visigoda. Madrid: BAC, 1979.

Gregorio De Tours. Histoire des Francs. Ed. e trad. de R. Latouche. Paris: Belles Lettres, 1966.

Hydácıo Chronicon. Ed. bilíngue (latim-francês) de A. Tranoy. 2v. Paris: Cerf, 1974. Hillgarth, J. N. Popular Religion in Visigothic Spain. In: James, E. (Ed.) Visigothic Spain: new approaches. Oxford: Claredon, 1980. 
Hillgart, J. N. Historiography in Visigothic Spain. In: La Storiografia Altomedievale. Settimane di Studio 17. Spoleto: CISAM, 1970, 2v.

Hillgarth, J. N. La conversión de los visigodos: notas críticas sobre un artículo reciente del profesor Thompson. AST 34, 1961.

Ildefonso De Toledo. De itinere desertii quo pergitur post baptismi. Ed. bilíngue (latim-espanhol) de J. Campos e I. Roca. In: Santos Padres Españoles. 2v. Madrid: BAC, 1971.

Isidoro de Sevilla. História Gothorum, Vandalorum et Suevorum. Ed. bilíngue (latim-espanhol) de C. Rodríguez Alonso. León: Centro de Estudios e Investigaciones "San Isidoro", 1975.

Isidoro de Sevilha. Etymologiarum. Ed. de Lindsay (latim). Trad. para o espanhol de J. O. Reta e M. A. A. Casquero, com introdução de M. C. Díaz y Díaz. 2v. Madrid: BAC, 1982.

Isidoro De Sevilha. Setentiarum. In: Santos Padres Españoles. 2v. Madrid: BAC, 1971.

Jones, A. H. M. El trasfondo social de la lucha entre el paganismo y el cristianismo. In: Momigliano, A. (ed) El conflito entre el paganismo y el cristianismo en el siglo IV. Madrid: Alianza, 1989.

Juan de Bíclaro Chronicon. Ed. Crítica de J. Campos Juan de Bíclaro, obispo de Gerona. Su vida y su obra. Madrid: CSIC, 1960.

Kieckhefer, R. La magia en la Edad Media. Barcelona: Crítica, 1992.

KInG, P. D. Derecho y Sociedad en el Reino Visigodo. Madrid: Alianza, 1981.

LE Goff, J. El cristianismo medieval en el Occidente desde el Concilio de Nicea (325) hasta la Reforma (principios del siglo XVI). In: Puech, C. H. (dir) Historia de las religiones.Las religiones constituidas en el Occidente y sus contracorrientes I. 12v. (Trad.esp.). Madrid: Siglo XXI, 1981.

LE Goff, J. Cultura clerical e tradições folclóricas na civilização merovíngia In: Le Goff, J. Para um novo conceito de Idade Média. Tempo, trabalho e cultura no Ocidente. Lisboa: Estampa, 1979.

LE Goff, J. As mentalidades: uma história ambígua. In: Le Goff, J.; NorA, P. (dir.) História: novos objetos. Rio de Janeiro: Francisco Alves, 1976.

Lex Visigothorum. Ed. K. Zeumer. MGH. Leges I.1. Hanover-Leipzig: Imprensis Bibliopolii Hahniani, 1973.

Lynch, C. H. e P. Galindo. San Braulio, obispo de Zaragoza (631-651). Su vida y sus obras. Madrid: Instituto “Enrique Florez"-CSIC, 1950.

Mangas, J. Hispania Romana. In: Tuñon De LARA, M. (dir) Historia de España I. Introducción, primeras culturas y Hispania romana. 11v. 3ed. Barcelona: Labor, 1982. 
Marrou, H. I. Desde el concilio de Nicea hasta la muerte de San Gregorio Magno. In: Knowles, M. D. et al. (dir) Nueva Historia de la Iglesia I. Desde los orígenes a San Gregorio Magno. Madrid: Cristandad, 1964.

Martínez, V. El paganismo en la España visigoda. Burgense, 13, 1972.

Martinho De Braga. De correctione rusticorum. Ed. bilíngüe (latim-espanhol) de R. Jove Clos. Barcelona: El Albir, 1981.

Matтoso, J. Breve interpretação do fenômeno priscilianista. In: Mattoso, J. (dir) História de Portugal I. Antes de Portugal. Lisboa: Estampa, 1993.

Mckenna, S. Paganism and Pagan Survivals in Spain up to the Fall of the Visigothic Kingdom. Washington DC: The Catholic University of America, 1938.

Momigliano, A. El conflicto entre el paganismo y el cristianismo. In: Momigliano, A. (ed) El conflito entre el paganismo y el cristianismo en el siglo IV. Madrid: Alianza, 1989.

Nola, A. Sagrado/Profano. In: ROMANO, R. (dir.) Encilopédia Einaudi. 41v. Lisboa: Imprensa Nacional - Casa da Moeda, 1987.

Olivares Guillem, A. Prisciliano a través del tiempo. Historia de los estudios sobre el Priscilianismo. S/L, Collección Galicia Histórica, Fundación Pedro Barrié de la Maza, 2004.

Orlandis, J. Historia de España. La España Visigoda. Madrid: Gredos, 1977.

Orlandis, J. La conversión de Europa al cristianismo. Madrid: Rialp, 1988.

OrLANDIS, J. "El cristianismo y la Iglesia en la España visigoda. In: Jover ZAMOrA, J. M. (dir.). Historia de España Menéndez Pidal. España Visigoda. T.III, 2v. Madrid, Espasa-Calpe, 1991.

Paulo Orósio. Historia Adversum Paganos. Ed. bilíngue (latim-espanhol) de C. Torres Rodrígues. Santiago: Instituto “P. Sarmiento” de Estudios Galegos, 1985.

Prieto Arciniega, A. Problemas sobre la romanización de la Península Ibérica. In: Estudios de Historia de España. Homenaje a Manuel Tuñon de Lara. Madrid: Universidad Internacional Menéndez Pelayo, 1981.

RAmos-Lissón, D. Los concilios hispánicos antes de la conversión de Recaredo. In: Orlandis, J.; Ramos-Lissón, D. Historia de los Concílios de la España Romana y Visigoda. Pamplona: Ediciones Universidad de Navarra, 1986.

Roblin, M. Paganisme et rusticité - une gros problème, une étude des mots. AESC $8,1953$.

SÁnchez-Albornoz, C. En torno a los orígenes del feudalismo I. Fideles y gardingos en la monarquia visigoda. Raíces del vasallaje y del beneficio hispanos. Buenos Aires: EUDEBA, 1974.

Schmitт, J-C. "Religion Populaire" et culture folclorique. AESC, 31, 1976. 
Schmitt, J-C. Les 'superstitions' In: Le Goff, J. e Rémond, R. (dir) Histoire de la France Religieuse. 4v. Paris Seuil, 1988.

Simon, M.; Benoit, A. Judaísmo e cristianismo antigo. De Antíoco Epifânio a Constantino. São Paulo: Pioneira - Edusp, 1987.

Sotomayor Y Muro, M. La Iglesia en la España romana. In: Garcìa- Sulpício Severo. Chronicon. In: Sulpício Severo. Obras Completas. Trad. de C. Codoñer Merino. Madrid: Tecnos, 1987.

Villoslada, R. (dir) Historia de la Iglesia en España I. La Iglesia en la España romana y visigoda. Madrid: BAC, 1979.

Teillet, S. Des Goths à la Nation Gothique. Les origines de l'idée de nation en Occident du Ve au VIIe siècle. Paris: Belles Lettres, 1984.

Thompson, E. A. Los godos en España. Madrid: Alianza, 1971.

Thompson, E. A. The visigoths in the time of Ulfila. Oxford: Oxford University Press, 1966. Thompson, E. A. Peasant revolts in late roman Gaul and Spain. Past and Present, 2, 1952.

Torres LoPez, M. Instituciones económicas, sociales e politicoadministrativas de la Península Hispánica durante los siglos V, VI y VII. In: Mené́ndez Pidal, R. (dir) Historia de España III. España visigoda (414-711). 3ed. Madrid: Espasa-Calpe, 1976.

Valdeavellano, L. G. Curso de historia de las instituciones españolas. Madrid: Alianza, 1982.

VIGIL, M. e A. CABo. Historia de España Alfaguara I. Condicionamientos geográficos y Edad Antigua. 4ed. Madrid: Alianza, 1978.

Vitas Sanctorum Patrum Emeritensium. Ed. bilíngue (latim-inglês) de J. N. Garvin. Washington DC: The Catholic University of América Press, 1946. 